\title{
PENAMBAHAN SUPLEMEN ZINC (Zn) PADA SINKRONISASI ESTRUS KAMBING RAS CAMPURAN
}

\author{
Muhammad Rosyid Ridlo', Agung Budiyanto² \\ ${ }^{1}$ Program Studi Kesehatan Hewan/Departemen Teknologi Hayati dan Veteriner/Sekolah Vokasi, Universitas Gadjah Mada, Indonesia \\ Email: ${ }^{1}$ rosyidridlodrh@gmail.com \\ ${ }^{2}$ Departemen Reproduksi dan Obstetri/Fakultas Kedokteran Hewan, Universitas Gadjah Mada, Indonesia \\ Email: ªgung_bd2004@yahoo.com
}

\begin{abstract}
The aim of this study was to understand the effect of using Zinc (Zn) to oestrous synchronization in Indonesian Mixed Breed Goat. The number of 12 does aging 24-36 months and a buck were used in this experiment in order to natural copulation purpose. The experimental animals were devided into 2 groups. The first group was given oestrous synchronization using polyurethane sponge which contained of medroxi progesterone acetate $60 \mathrm{mg}$ through intra vaginal for 14 days (control). The Second group was synchronized in the same method as the first group and supplemented with $\mathrm{Zn} 20 \mathrm{mg} / \mathrm{head}$ by peroral. The does that have been oestrous then mated naturally. The experimental results indicate the number of natural copulation in second group was higher than control ( $83 \%$ vs $50 \%$ ). Oestrous uniformity occurred in both groups. The Oestrous onset in second group was earlier than control (36 vs 48 jam) and duration of oestrous was longer than control (12 vs $48 \mathrm{jam}$ ).

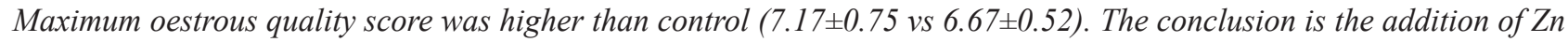
Supplement improves the quality of oestrous during oestrous synchronization by intra vaginal polyurethane sponge which contained of medroxi progesterone acetate $60 \mathrm{mg}$ in Indonesian mixed breed goat.
\end{abstract}

Keywords: Zinc (Zn), oestrous synchronization, Indonesian mixed breed goat, medroxi progesterone acetate.

\section{PENDAHULUAN}

Bertambahnya jumlah penduduk mendorong peningkatan jumlah kebutuhan pangan pada suatu negara. Daging sebagai sumber protein hewani tentunya juga mengalami peningkatan permintaan sebagai bahan protein yang sangat penting bagi kecerdasan dan kekuatan bangsa. Potensi pasar daging kambing ini hendaknya disikapi dengan upaya peningkatan produksi hewan dalam hal ini adalah komoditas kambing. Selain itu, meningktanya tren susu kambing di masyarakat juga menjadi peluang tersendiri bagi peternak kambing perah. Berkaitan dengan peningkatan permintaan di sektor kambing pedaging dan perah perlu adanya manajemen reproduksi dalam sebuah peternakan maupun suatu wilayah dengan jumlah penduduk yang besar seperti Indonesia. Apabila permintaan yang tinggi tidak diimbangi dengan peningkatan produksi kambing, maka dikhawatirkan akan terjadi ketidakseimbangan antara demand dan supply.

Pada kenyataannya, perkembangan populasi kambing di Indonesia cenderung lambat tidak sejalan dengan jumlah permintaan lokal maupun tujuan ekspor (Karokaro, 2004). Populasi kambing di Indonesia pada tahun 2014 sebesar 19.216.000 ekor dengan angka pertumbuhan sekitar 3,5\% (Badan Pusat Statistik, 2015). Pertumbuhan ini dinilai masih perlu ditingkatkan mengingat pemerintah sedang giat menggalakkan program swasembada daging untuk Indonesia sehingga untuk meningkatkan kuantitas dan kualitas reproduksi kambing di Indonesia perlu ada terobosan yang positif. Terobosan ini tidak hanya dari tingkat universitas namun juga disertai dengan elemen lain misalnya dari sektor pemerintahan dan swasta.

Sinkronisasi estrus dapat menjadi salah satu terobosan penting dalam mendukung peningkatan produksi hewan ternak dalam hal ini adalah kambing atau domba. Pelaksanaan sinkronisasi estrus merupakan usaha penyeragaman estrus pada kambing dengan bantuan hormon. Sinkronisasi estrus dapat dimodifikasi dengan beberapa tambahan perlakuan, misalnya dengan penambahan suplementasi mikro mineral berupa Zinc $(\mathrm{Zn})$. Secara alamiah dalam suatu kelompok hewan ternak, waktu estrus pada masing-masing individu tidak tejadi secara seragam. Oleh karena itu, apabila peternak hanya mengandalkan waktu estrus alami maka peternak membutuhkan banyak hari untuk menunggu seluruh hewan ternaknya estrus sehingga peternak akan kehilangan banyak waktu dan tenaga untuk mengawinkan ternaknya. Penyeragaman waktu estrus dapat dilakukan dengan bantuan hormon progesteron. Spon intra vaginal yang mengandung medroxi progesterone acetate $60 \mathrm{mg}$ diinsersikan ke dalam saluran vagina kambing selama 14 hari ditambah suplementasi mineral $\mathrm{Zn}$ akan menyeragamkan waktu estrus pada kambing yang diinginkan. Jumlah dan waktu pelaksanaan menyesuaikan kebutuhan peteternak. Metode ini akan memudahkan manajemen pemeliharaan dalam pengaturan kelahiran, kebuntingan, dan masa laktasi.

Penelitian ini bermaksud untuk mencari metode dalam rangka meningkatkan kualitas estrus pada sinkronisasi estrus. Kombinasi antara sinkronisasi estrus menggunakan spon intra vaginal yang mengandung medroxi progeeterone acetae 60 
$m g$ dan penambahan Zinc (Zn) belum pernah dilakukan dalam penelitian sebelumnya. Zinc merupakan mikro mineral yang sangat berperan positif terhadap reproduksi hewan betina sehingga dengan kombinasi perlakuan ini diharapkan mampu meningkatkan kualitas estrus dan mampu meningkatkan produktifitas peternakan kambing.

Faktor yang berperan penting dalam sistem reproduksi selain hormonal adalah mineral seng ( $\mathrm{Zn})$. Mineral $\mathrm{Zn}$ berperan dalam sintesis estrogen dan progesteron, bertanggung jawab atas keberadaan histone H3K4 trimethylation dan global DNA methylation. Keduanya sangat penting dalam pertumbuhan dan maturasi oosit. Proses completion of meiosis oosit dan aktivasi oosit secara in vitro juga dipengaruhi oleh Zn. Mencit yang mengalami Zinc Deficient Diet (ZDD) selama 3-5 hari sebelum ovulasi akan mengalami masalah pada oocyte chromatin methylation dan gangguan pada perkembangan implantasi fetus, kerusakan oocyte epigenetic programming yang berdampak pada kegagalan ovulasi dan penyimpangan ekspresi gen oosit. Kekurangan $\mathrm{Zn}$ dapat menurunkan $I g f 2$ dan $H 19$ yang berakibat pada rendahnya keberhasilan fertilisasi dan viabilitas embrio. Igf2 dan H19 merupakan locus gene yang berperan dalam proses oogenesis pada oosit (Tian dan Diaz, 2012). Oleh karena itu, penambahan $\mathrm{Zn}$ sangat berpengaruh terhadap pekembangan folikel dan sistem reproduksi betina kambing.

Sinkronisasi yang berkualitas tentunya akan sangat membantu peternak dalam pelaksanaan program reproduksi kambing di peternakannya. Penggunaan sistem sinkronisasi estrus akan memudahkan peternak dalam mengatur jumlah hewan yang akan diprogramkan untuk bunting. Peternak juga akan mudah mengatur kapan waktu panen dan kapan waktu laktasi pada kambing perah. Keunggulan sistem sinkronisasi estrus ini diharapkan dapat membantu meningkatkan produktifitasnya, baik secara kualitas dan kuantitas, sehingga kecukupan akan daging dan susu kambing dapat terpenuhi.

\section{BAHAN DAN METODE PENELITIAN}

Penelitian ini dilakukan di Kandang Peternakan Bhumi Nararya Farm, Daerah Istimewa Yogyakarta dengan sistem perkandangan kandang panggung. Hewan coba di dalam kandang dipisahkan oleh sekat kayu. Setiap petak terdiri dari 2 hingga 3 ekor kambing. Pemberian pakan diberikan seragam dan air minum selalu tersedia. Ketinggian lokasi peternakan berada pada $410 \mathrm{mdpl}$ dengan temperatur lingkungan $21.8^{\circ} \mathrm{C}-24^{\circ} \mathrm{C}$ serta kelembaban udara $77 \%-87 \%$.

Hewan coba yang digunakan dalam penelitian ini adalah kambing ras campuran. Kambing betina yang digunakan sebagai penelitian sebanyak 12 ekor dengan kisaran umur 24-36 bulan. Kambing betina merupakan jenis ras campuran hasil persilangan beberapa jenis kambing antara lain Saanen, Boer, Peranakan Etawa, Jawa Randu, Alpine. Kambing yang telah dipilih kemudian diberi perlakuan, selanjutnya dikawinkan secara alami.

Spon polyurethane yang dibentuk silinder dengan ukuran $2 \times 2 \times 2 \mathrm{~cm}$ dengan pengikat tali nylon sepanjang $20 \mathrm{~cm}$ digunakan sebagai bahan pembawa hormon. Hormon yang digunakan adalah progesteron (medroxi progesterone acetate $60 \mathrm{mg}$ ), sedangkan suplemen Seng (Zn) $20 \mathrm{mg}$ diberikan secara peroral. Bahan lain yang digunakan adalah pipa aplikator spon intra vaginal, syringe $5 \mathrm{ml}$ dan $10 \mathrm{ml}$, kamera, lampu, gloves, pen light.

Metode penelitian ini menggunakan dua kelompok perlakuan, yaitu kelompok pertama sebagai kontrol dan kelompok kedua sebagai kelompok perlakuan. Kambing yang telah diseleksi dikelompokkan secara acak menjadi dua kelompok, masing-masing kelompok terdiri dari 6 ekor kambing betina. Seluruh hewan coba diberi perlakuan sinkronisasi estrus dengan metode implant spon polyurethane secara intra vaginal. Spon berisi medroxi progesterone acetate $60 \mathrm{mg}$ dimasukkan ke dalam saluran vagina di depan mulut cervix selama 14 hari. Spon dikeluarkan pada hari ke-14 dari vagina (PI). Perlakuan kelompok kedua ditambahkan suplemen Zn (Zink elemental $20 \mathrm{mg}$ /ekor) per oral sebanyak 7x diberikan dengan interval 48 jam (2 hari), dimulai pada hari pemasangan spon intra vaginal (PII).

Pengamatan kualitas estrus dilakukan pada hari ke-24, 36, 60, 72, dan 84 jam setelah sinkronisasi estrus (pelepasan spon intra vaginal). Deteksi estrus dilakukan dengan cara pengamatan visual serta menggunakan kambing pejantan sebagai detektor estrus alami. Seluruh hewan yang mengalami estrus akan dikawinkan dengan pejantan secara alami.

Parameter yang diamati dalam penelitian ini adalah 1) Skor kualitas estrus secara visual, 2) Keseragaman estrus, 3) Waktu kemunculan esrus, 4) Durasi estrus, 5) Kejadian kawin alam. Kriteria kualitas estrus yang digunakan penilaian adalah perilaku hewan betina, perubahan penampakan vulva, perubahan warna dan lendir servik. Penilaian estrus dilakukan dengan menghitung nilai dari masing-masing kriteria estrus kambing. Pengolahan analisis data menggunakan Metode Uji Statistik Anova dan T-Test. Pembahasan hasil pengamatan dijelaskan secara deskriptif.

Parameter penilaian kualitas estrus secara visual ditinjau dari tiga aspek utama yaitu: keadaan vulva, lender serviks, dan tingkah laku. Penilaian keadaan vulva dibedakan menjadi 4 tingkatan skor. Vulva dengan keadaan bengkak (oedematous), mukosa merah diberikan skor 3; apabila kebengkakan tidak maksimal dan mukosa kemerahan diberikan skor 2; keadaan vulva dengan adanya perubahan kebengkakan vulva dan warna pink tua atau kemerahan namun tidak begitu jelas diberikan skor 1; vulva tidak mengalami perubahan bentuk atau warna (pink) diberikan skor 0. Penilaian 
lendir serviks dengan keberadaan lendir yang banyak, terdapat leleran lendir di ekor, pantat, lantai diberikan skor 3; lendir dalam jumlah sedang dan atau berupa leleran di sekitar vulva diberikan skor 2; lendir vulva terlihat sedikit ketika vulva dibuka diberikan skor 1; sedangkan vulva yang tidak berlendir diberikan skor 0. Penilaian tingkah laku betina yang sering mengembik, naik-naik dinding kandang, tertarik terhadap pejantan dan diam dinaiki diberikan skor 3; betina yang tertarik terhadap pejantan, mengibaskan ekor, diam dinaiki diberikan skor 2; keadaan betina yang belum mau dinaiki namun sudah sering mengibaskan ekor diberikan skor 1 ; betina yang tidak mau dinaiki dan tidak sering mengibaskan ekor diberikan skor 0 (Tabel. 1).

\subsection{Hasil dan pembahasan}

Pelaksanaan sinkronisasi estrus dalam penelitian ini tidak mengalami kendala. Penggunaan spon intra vaginal dan $\mathrm{Zn}$ tidak memberikan dampak negatif terhadap nafsu makan dan tingkah laku hewan coba. Secara umum pada kedua kelompok menunjukkan tanda-tanda estrus berupa pembengkakan pada area vagina, munculnya lendir, dan terjadi hyperemia (kemerahan) pada mukosa vagina. Tanda tanda yang lain adalah adanya ketertarikan hewan betina terhadap pejantan. Hal ini terlihat pada tingkah laku betina menaiki batas kandang, mendekat ke arah pejantan serta diam pada saat pejantan menaiki punggung betina.

\subsection{Hasil Pengamatan Skor Penilaian Kualitas Estrus}

Pengamatan pada penelitian sinkronisasi estrus ini menunjukkan kemunculan tanda-tanda estrus berdasar pengamatan secara visual dan dengan bantuan kambing pejantan. Tanda estrus tersebut dikelompokkan menjadi beberapa kriteria dan penilaian. Penilaian estrus dibedakan menjadi tiga kriteria, yaitu: perubahan vulva, lendir cerviks, dan tingkah laku. Masing-masing kriteria memiliki skor penilaian antara 0 hingga 3. Skor 0 menunjukkan kualitas estrus terendah dan skor 3 menunjukkan kualitas estrus paling tinggi (Tabel 1).

Tabel 1. Kriteria penilaian estrus pada kambing

\begin{tabular}{lcl}
\hline Kriteria & Skor & \multicolumn{1}{c}{ Keterangan } \\
\hline Keadaan vulva & 3 & Bengkak (oedematous), mukosa merah \\
& 2 & Kebengkakan tidak maksimal dan mukosa kemerahan \\
& 1 & Terdapat perubahan kebengkakan vulva dan warna pink tua atau kemerahan \\
& & namun tidak begitu jelas \\
Lendir serviks & 3 & Vulva tidak mengalami perubahan bentuk atau warna (pink) \\
& 2 & Lendir sedang, berupa leleran di sekitar vulva \\
& 1 & Lendir sedikit, terlihat ketika vulva dibuka \\
& 0 & Tidak berlendir \\
Tingkah laku & 3 & Sering mengembik, naik-naik dinding kandang, tertarik terhadap pejantan, diam \\
& & dinaiki \\
& 2 & Tertarik terhadap pejantan, mengibaskan ekor, diam dinaiki \\
& 1 & Belum mau dinaiki, mengibaskan ekor \\
& 0 & Tidak mau dinaiki pejantan \\
\hline
\end{tabular}

Pengamatan kualitas estrus didasarkan penilaian skor pada Tabel 1. Waktu pengamatan dilakukan pada jam ke24, 36, 48, 60, 72, dan 84 pasca pelepasan spon. Hasil pengamatan menunjukkan bahwa pada pengamatan 24 jam pasca sinkronisasi estrus sudah terlihat perubahan tanda estrus namun belum begitu jelas. Penampakan estrus terlihat jelas pada jam ke-48 dan 60 pasca sinkronisasi. Sedangkan pada jam ke- 60, 72, dan 84 terjadi penurunan secara bertahap. Kedua perlakuan memperlihatkan pola yang sama, namun kualitas estrus pada penambahan Zn menunjukkan kualitas estrus yang lebih baik pada setiap jam pengamatan.

Grafik pada Gambar 1 mengenai skor penilaian kualitas estrus pada sinkronisasi estrus kambing ras campuran menunjukkan terjadi perubahan kondisi vulva, lendir cervix atau tingkah laku kambing betina pada hari pertama (24 jam) pasca sinkronisasi. Pergerakan kanaikan perubahan semakin terlihat pada 36 jam pasca sinkronisasi. Puncak estrus terjadi pada jam ke-48 dan 60 pasca sinkronisasi. Pergerakan penurunan kualitas sinkronisasi terlihat pada jam ke-72 dan 84 setelah sinkronisasi estrus. Berdasarkan data yang diperoleh pada semua waktu pengamatan menunjukkan kualitas estrus pada perlakuan Zn (P II) lebih baik dibadingkan kontrol. 
Perubahan yang mulai terlihat pada pengamatan jam ke-36 pasca sinkronisasi, menunjukkan kualitas estrus yang lebih tinggi $(5,17)$ pada perlakuan Zn (P II) dibanding kelompok kontrol (P I). Pengamatan jam ke-48 dan 72 terjadi peningkatan yang jelas pada kedua kelompok. Hal ini menunjukkan terjadinya puncak kualitas estrus serta terjadi sinkronisasi estrus pada kelompok P I dan P II. Berdasar hasil pengamatan, skor maksimal estrus pada P II lebih tinggi dibandingkan P I. Perbedaan ini menunjukkan bahwa pada penambaan Zn (P II) memiliki kualitas estrus yang lebih baik $(7,17 \pm 0,75)$ dibandingkan dengan kontrol (P I) $(6,67 \pm 0,52)$ (Tabel 2).

Peningkatan kualitas estrus pada kelompok perlakuan disebabkan karena penambahan Zn selama 7x diberikan. Hal ini sesuai dengan penelitian yang berkaitan dengan pemberian suplemen mineral tambahan yang mengungkapkan bahwa penambahan mineral Zn dapat membantu meningkatkan performa reproduksi (Vinoles et al., 2009). Performa reproduksi jelas terlihat pada pengamatan bahwa kualitas estrus, tingkat kebengkakan, warna kemerahan, dan jumlah lendir lebih baik pada kelompok Zn (P II) dibandingkan kelompok kontrol tanpa penambahan Zn. Penelitian terkait mineral dengan Metode Eliminasi Nutrisi Zinc Deficient Diet (ZDD) pada mencit selama 3-5 hari sebelum ovulasi menunjukkan permasalahan pada proses meiosis oosit, angka fertilisasi yang rendah, perkembangan fetus yang buruk hingga gangguan implantasi fetus. Kekurangan $\mathrm{Zn}$ pada masa menjelang ovulasi berpengaruh negatif pada proses perkembangan seluler oosit dan sistem reproduksi hewan (Tian dan Diaz, 2013). Berdasarkan data tersebut penambahan Zn diyakini dapat meningkatkan perkembangan seluler oosit dan sistem reproduksi hewan baik itu di dalam ovarium, hormonal maupun keadaan luar alat reproduksi betina.

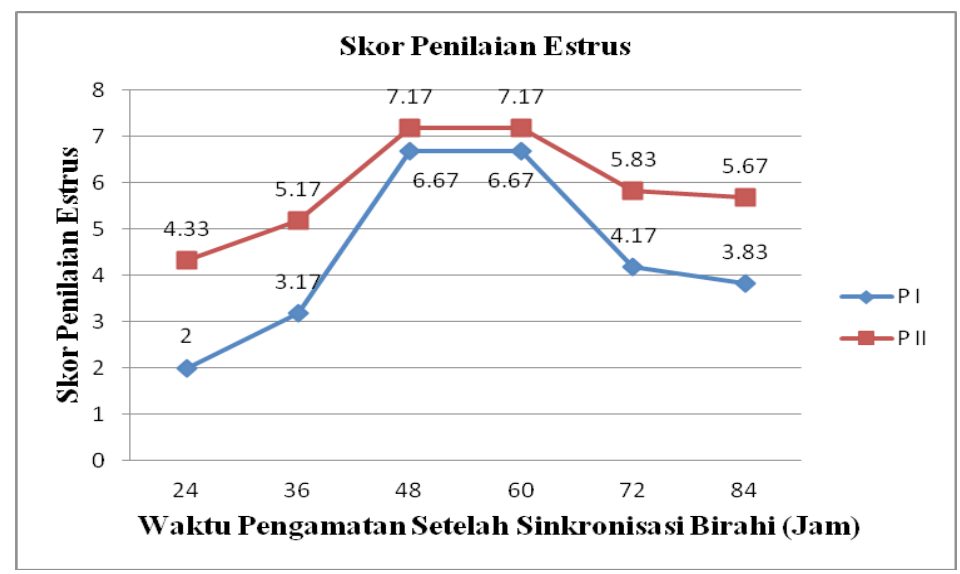

Gambar 1. Grafik skor penilaian kualitas estrus pada sinkronisasi estrus kambing ras campuran

Secara statistik, perbedaan skor penialaian estrus pada kelompok kontrol menunjukkan perbedaan yang nyata pada jam ke-24 terhadap kelompok P II. Skor kelompok P I sebanyak 2 sedangkan pada P II adalah 4,33. Secara visual terlihat bahwa terdapat perbedaan di mana kelompok P II sudah menunjukkan perubahan warna yang kemerahan dan mulai ada tanda oedematous. Meskipun secara statistik skor penilaian estrus antara kedua kelompok pada jama ke-36, 48, 60, 72, 84 pasca sinkronisasi tidak menunjukkan perbedaan yang nyata, namun secara visual terlihat perbedaan antara kedua kelompok. Kelompok Zn (P II) terlihat memiliki tanda-tanda estrus yang lebih nyata (Tabel 2). Skor penilaian estrus pada kelompok P II menunjukkan lebih baik dibanding kelompok kontrol.

Tabel 2. Penilaian kualitas estrus pada jam ke-24, 36, 48, 60, 72, 84 setelah sinkronisasi estrus

\begin{tabular}{ccccccc}
\hline Perlakuan & $\begin{array}{c}\text { 24 Jam } \\
(\mathbf{m e a n} \pm \mathbf{s d})\end{array}$ & $\begin{array}{c}\mathbf{3 6 ~ J a m} \\
(\mathbf{m e a n} \pm \mathbf{s d})\end{array}$ & $\begin{array}{c}\mathbf{4 8} \mathbf{J a m} \\
(\mathbf{m e a n} \pm \mathbf{s d})\end{array}$ & $\begin{array}{c}\text { 60 Jam } \\
(\mathbf{m e a n} \pm \mathbf{s d})\end{array}$ & $\begin{array}{c}\text { 72 Jam } \\
(\mathbf{m e a n} \pm \mathbf{s d})\end{array}$ & $\begin{array}{c}\text { 84 Jam } \\
(\mathbf{m e a n} \pm \mathbf{s d})\end{array}$ \\
\hline Kontrol & $2 \pm 0,0^{\mathrm{a}}$ & $3,17 \pm 1,17^{\mathrm{b}}$ & $6,67 \pm 0,52^{\mathrm{b}}$ & $6,67 \pm 0,52^{\mathrm{b}}$ & $4,17 \pm 1,33^{\mathrm{b}}$ & $3,83 \pm 1,47^{\mathrm{b}}$ \\
$\mathrm{Zn}$ & $4,33 \pm 1,03^{\mathrm{b}}$ & $5,17 \pm 1,72^{\mathrm{b}}$ & $7,17 \pm 0,75^{\mathrm{b}}$ & $7,17 \pm 0,75^{\mathrm{b}}$ & $5,83 \pm 1,72^{\mathrm{b}}$ & $5,67 \pm 2,07^{\mathrm{b}}$ \\
\hline
\end{tabular}

Keterangan: Nilai dalam satu kolom dengan superskrip yang berbeda $(a, b)$ menunjukkan perbedaan yang nyata pada $p<0,05$.

\subsection{Keseragaman Estrus}

Keseragaman estrus terlihat pada kedua kelompok perlakuan. Keseragaman estrus diamati pada pengamatan jam ke-48 dan 60 pasca sinkronisasi. Perlakuan Zn (PII) menunjukkan terjadi estrus yang seragam sehingga dengan pemberian 
Zn masih menunjukkan terjadi keseragaman estrus dan tidak bepengaruh negatif terhadap keseragaman estrus (Tabel 3). Terjadinya esrus secara serentak karena pada saat insersi spon intra vaginal medroxi progesterone acetate $60 \mathrm{mg}$, maka secara fisologis terjadi peningkatan kadar progesteron sehingga hal ini akan menahan kadar progesteron pada kondisi yang tinggi sedangkan konsentrasi estrogen akan menurun selama 14 hari. Pelepasan spon pada hari ke-14 akan menyebabkan menurunnya kadar progesteron secara drastis (Amen dan Al-Daraji, 2011). Secara fisiologis, jika terjadi penurunan maka hormon estrogen akan segera naik munuju keseimbangan. Naiknya kadar estrogen ini diikuti dengan perkembangan FollicleStimulating Hormone (FSH) sehingga terjadilah ektivitas perkembangan folikel di dalam ovarium. Peningkatan folikel ovarium hinga tahap folikel de graaf mengakibatkan terjadinya tanda-tanda estrus pada vagina muncul. Perubahan tersebut terjadi pada area vagina sebagai proses alami persiapan proses perkawinan. Perubahan tersebut antara lain pembengkakan pada vagina, warna kemerahan, dan munculnya lendir cervix yang bening (Gonzales dan Veiga, 2005).

Keseragaman estrus tejadi pada hari jam ke-48 hingga 60 pasca pelepasan spon puncak estrus terjadi pada kedua kelompok. Selang waktu ini diperlukan oleh folikel kambing untuk bekembang. Perkembangan folikel dengan ukuran $\geq 3 \mathrm{~mm}$ yang memiliki efek pada kualitas estrus menuju ke folikel yang memiliki ukuran 6-9 $\mathrm{mm}$ yang disebut sebagai folikel dominan memerlukan waktu 30-60 jam (Yacoub, 2011). Hal ini seperti yang terjadi dalam penelitian ini waktu keseragaman puncak estrus terjadi pada jam ke 48-60 jam pasca sinkronisasi (Tabel 3), sedangkan waktu waktu ovulasi terjadi pada 12-36 jam setelah terjadi estrus (Noakes et al., 2008).

Terjadinya keseragaman estrus ini menunjukkan kedua metode memberikan hasil yang baik dalam pelaksanaan sinkronisasi estrus. Hal ini terlihat pada kedua metode perlakuan dapat menghasilkan kambing betina estrus dan terjadi secara seragam. Sinkronisasi estrus menggunakan medroxi progesterone acetate $60 \mathrm{mg}$ mampu menginduksi terjadinya sinkronisasi yang seragam. Penggunaan Zinc dalam perlakuan kelompok P II terbukti tidak mengganggu kejadian sinkronisasi estrus. Hal ini menunjukkn penggunaan $\mathrm{Zn}$ tidak bertentangan terhadap perlakuan sinkronisasi estrus dengan Metode Spon Intra Vaginal mengandung medroxi progesterone acetate $60 \mathrm{mg}$. Manfaat lain yang diperoleh dalam penelitian ini adalah penggunaan $\mathrm{Zn}$ dapat membantu meningkatkan kualitas estrus hasil sinkronisasi estrus pada kambing ras campuran Indonesia.

Tabel 3. Hasil pengamatan kejadian estrus pada sinkronisasi estrus kambing

\begin{tabular}{ccccc}
\hline Perlakuan & $\begin{array}{c}\text { Jumlah hewan } \\
\text { coba (ekor) }\end{array}$ & Kejadian estrus & $\begin{array}{c}\text { Persentase } \\
(\mathbf{\%})\end{array}$ & Keseragaman \\
\hline Kontrol & 6 & 6 & 100 & Sinkron/Seragam \\
$\mathrm{Zn}$ & 6 & 6 & 100 & Sinkron/Seragam \\
\hline
\end{tabular}

\subsection{Waktu Kemunculan Esrus}

Pelepasan spon pada perlakuan sinkronisasi dilakukan pada waktu yang sama yaitu pada hari ke-14 terhitung pada saat pemasangan spon intra vaginal. Terjadi perbedaan hasil nilai skor kualitas estrus pada kedua perlakuan. Kelompok $\mathrm{P}$ II menunjukkan tanda-tanda estrus sudah mulai terlihat lebih jelas pada jam ke-36 lebih cepat dibandingkan dengan kontrol pada jam 48 pasca pelepasan spon (Tabel 4). Perubahan ini bisa disebabkan karena pengaruh pemberian Zn. Pengaruh Zn membantu memperbaiki kualitas folikulogenesis oosit sehingga jumlah folikel yang berkembang menjadi lebih banyak serta kualitasnya lebih baik (Kundu et al., 2014). Cavalcanti et al. (2012) menyebutkan bahwa interval estrus pada pemberian intra vaginal sponge menggunakan medroxi progesterone acetate $60 \mathrm{mg}$ dapat terjadi pada saat $32 \pm 7,4$ jam dengan durasi estrus (panjang estrus) 37,4 $\pm 9,0$ jam setelah sinkronisasi estrus. Hasil penelitian tersebut mendukung penelitian ini yang menunjukkan gejala estrus pada kontrol dan kelompok Zn terlihat pada 36 dan 40 jam setelah sinkronisasi estrus. Waktu kemunculan estrus dan durasi estrus pada kontrol dan kelompok Zn sesuai dengan hasil penelitian yang dilakukan oleh Cavalcanti et al (2012). Penelitian tersebut menyebutkan bahwa kejadian waktu kemunculan estrus dan durasi estrus berturut-

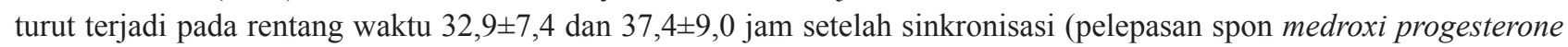
acetate $60 \mathrm{mg}$ ) (Cavalcanti et al., 2012).

Tabel 4. Hasil pengamatan kemunculan waktu estrus setelah sinkronisasi estrus

\begin{tabular}{ccc}
\hline Perlakuan & $\begin{array}{c}\text { Jumlah hewan coba } \\
\text { (ekor) }\end{array}$ & $\begin{array}{c}\text { Waktu estrus setelah } \\
\text { sinkronisasi estrus } \\
\text { (jam) }\end{array}$ \\
\hline Kontrol & 6 & 48 \\
Zn & 6 & 36 \\
\hline
\end{tabular}




\subsection{Durasi Estrus}

Pengamatan terhadap durasi estrus pada kedua kelompok perlakuan menunjukkan perbedaan lama waktu estrus. Pada kelompok kontrol waktu terjadinya estrus adalah 12 jam. Terjadinya estrus diawali dengan adanya perubahan pada vulva namun pada jam ke-24 belum menunjukkan nilai skor kualitas estrus yang baik. Pengamatan pada jam ke-72 pasca sinkronisasi kelompok kontrol juga menunjukkan penurunan kualitas estrus lebih cepat sehingga lama waktu terjadinya estrus cenderung lebih pendek dibandingkan kelompok perlakuan Zn (P II). Pengamatan pada kelompok perlakuan Zn menunjukkan durasi estrus terjadi lebih lama yaitu selama 48 jam (Gambar 2). Hal ini terlihat pada pengamatan setelah dilakukan sinkronisasi estrus terlihat pada jam ke-24 pasca pelepasan spon belum menunjukkan tanda estrus yang tampak jelas.

Pengamatan estrus pada jam ke-36 pasca sinkronisasi sudah menunjukkan perubahan estrus dengan penilaian skor $5,17 \pm 1,72$, sedangkan pada pengamatan pada jam ke-48 dan 60 pasca sinkronisasi estrus terlihat kualita estrus sangat baik dengan skor $7,17 \pm 0,75$ yang merupakan skor tertinggi pada penelitian ini. Selanjutnya pada jam ke-72 dan 84 pasca sinkronisasi estrus terjadi penurunan kualitas skor estrus berturut-turut dari 5,83 $\pm 1,72$ menjadi 5,67 2,07. Namun demikian, penurunan hingga skor 5 masih menunjukkan tanda-tanda estrus meskipun sudah tidak maksimal.

Cavalcanti et al. (2012) menyebutkan bahwa interval estrus pada pemberian intra vaginal sponge menggunakan medroxi progesterone acetate $60 \mathrm{mg}$ dapat terjadi pada saat 32 $\pm 7,4$ jam dengan durasi estrus (panjang estrus) 37,4 $\pm 9,0$ jam setelah sinkronisasi estrus. Hasil penelitian tersebut mendukung penelitian ini yang menunjukkan gejala estrus pada kelompok kontrol dan kelompok Zn (P II) terlihat pada 36 jam setelah sinkronisasi estrus sedangkan durasi estrus menunjukkan 38 $\pm 17,66$ jam setelah sinkronisasi estrus. Durasi estrus pada sinkronisasi estrus dapat terjadi pula pada kisaran waktu 24-70 jam (Yacoub et al., 2011) dan pada rentang waktu 35,3 \pm 3,1 jam (Holtz et al., 2007).

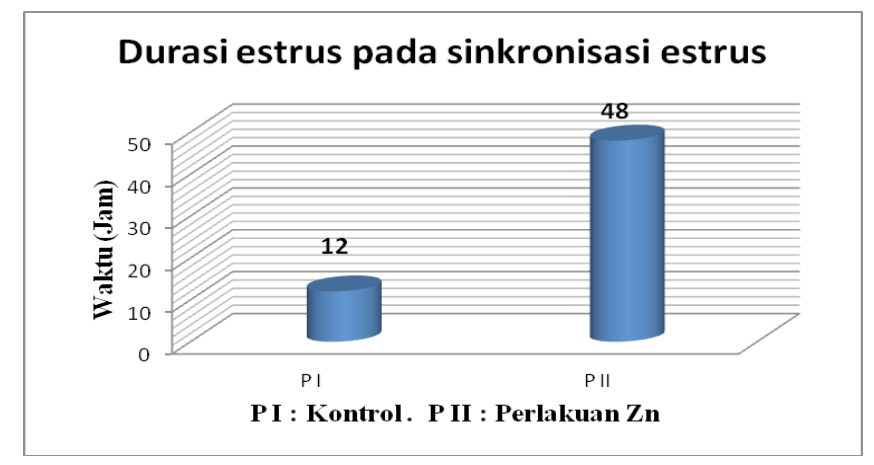

Gambar 2. Durasi estrus pada pelaksanaan sinkronisasi estrus

\subsection{Kejadian Kawin Alam}

Kejadian kawin alam yang diamati pada penelitian ini memberikan hasil yang bervariasi. Kawin alam pada kelompok kontrol (P I) mempelihatkan sebanyak 50\% dari hewan yang estrus terjadi kawin alam. Hasil yang diamati pada kelompok Zn (P II) menunjukkan 83\% kambing terjadi kawin alam pada hewan yang estrus (Tabel 5).

Berdasar kelompok yang mengalami sinkronisasi estrus, perlakuan Zn (P II) memiliki hasil yang lebih baik. Kelompok perlakuan Zn (P II) mampu menginduksi terjadinya sinkronisasi estrus dan memiliki tingkat kejadian kawin sebesar $83 \%$ pada kejadian estrus. Kambing yang terlihat memiliki gejala estrus belum tentu terjadi kawin alam. Hal ini tampaknya terkait insting pejantan yang hanya mau mengawini betina apabila kualitas estrus benar-benar bagus. Begitu pula jika kualitas estrus betina belum benar-benar bagus tidak akan mau dinaiki oleh pejantan untuk kawin alam. Hal ini menunjukkan bahwa dengan penambahan mineral Zn mampu meningkatkan kualitas estrus serta kejadian kawin alam. Penambahan Zn dalam penelitian ini mampu meningkatkan proses perkembangan dan kualitas folikulogenensis (Gonzales dan Veiga, 2005) sehingga estrus yang terjadi menjadi lebih optimal dengan tingkat kejadian kawin alam lebih tinggi (83\%) dibandingkan dengan kontrol (50\%).

Kambing pejantan secara alami hanya akan mengawini betina yang benar-benar estrus. Fenomena ini dapat membantu penelitian ini dalam menilai apakah kualitas estrus kambing yang dilakukan sinkronisasi estrus benar-benar memiliki kualitas estrus yang baik. Apabila betina belum dalam keadaan yang benar-benar baik, maka pejantan tidak akan mengawini betina walaupun secara visual sudah menunjukkan tanda-tanda estrus. Keadaan ini terlihat pada pengamatan penelitian ini bahwa secara penilaian skor estrus sudah menunjukkan gejala estrus $100 \%$, namun pada kelompok control kejadian kawin alam sebanyak 50\%. Begitu juga pada kelompok perlakuan Zn kejadian kawin alam sebesar 83\%. Hal 
yang menarik adalah pada kelompok perlakuan Zn menunjukkan tingkat kejadian kawin alam lebih tinggi (83\%) dibanding dengan kelompok kontrol (50\%).

Terjadinya estrus yang terlihat pada pengamatan bisa tidak disertai kejadian ovulasi. Perkembangan folikel akan berkembang dari fase folikel primer hingga menuju folikel de graaf. Proses yang terjadi saat estrus berlangsung adalah oosit telah berkembang pada tahap folikel yang matang di ovarium. Tahapan selanjutnya adalah ovulasi, yaitu proses pelepasan oosit dari ovarium menuju infundibulum. Oosit yang diovulasikan siap untuk proses fertilisasi (Frandson et al., 2009). Kegagalan ovulasi dapat terjadi jika pada saat sel telur sudah mencapai tahap folikel de graaf namun tidak tersedia Luteinizing hormone (LH) yang mencukupi maka yang terjadi adalah hewan terlihat estrus namun tidak terjadi ovulasi. Karena kecukupan LH berfungsi untuk proses ovulasi.

Tabel 5. Pengamatan kejadian kawin alam pada sinkronisasi estrus kambing

\begin{tabular}{cccc}
\hline Perlakuan & $\begin{array}{c}\text { Jumlah hewan coba } \\
\text { (ekor) }\end{array}$ & $\begin{array}{c}\text { Kawin alam pada } \\
\text { kejadian estrus } \\
\text { (ekor) }\end{array}$ & $\begin{array}{c}\text { Persentase } \\
\text { (\%) }\end{array}$ \\
\hline Kontrol & 6 & 3 & 50 \\
Zn & 6 & 5 & 83 \\
\hline
\end{tabular}

Pemberian mikromineral Seng (Zn) sebagai mineral tambahan dalam penelitian sinkronisasi birahi pada kambing ras campuran memberikan manfaat berdasarkan pengamatan visual maupun secara statistik. Berdasarkan hasil pengamatan menunjukkan dampak positif terhadap keseragaman dan kualitas estrus. Metode penyeragaman estrus menggunakan medroxi progesterone acetate $60 \mathrm{mg}$ /ekor dengan penambahan Zn menunjukkan keseragaman birahi pada kedua kelompok dengan kualitas estrus yang lebih baik daripada kelompok kontrol. Kemunculan estrus kelompok Zn menunjukkan waktu kemunculan estrus lebih cepat (36 vs 48 jam) dan durasi estrus lebih panjang (12 vs 48 jam). Skor maksimal kualitas estrus lebih tinggi dibandingkan dengan kelompok kontrol $(7,17 \pm 0,75$ vs $6,67 \pm 0,52)$. Hasil penelitian metode sinkronisasi menggunakan medroxi progesterone acetate $60 \mathrm{mg}$ pada spon intra vaginal dengan penambahan suplemen Zn menunjukkan hasil yang lebih baik dan mampu meningkatkan kualitas estrus kambing ras campuran Indonesia.

\section{KESIMPULAN}

Penambahan Zinc $(\mathrm{Zn})$ pada sinkronisasi estrus menggunakan spon intra vaginal mengandung medroxi progesterone acetate $60 \mathrm{mg}$ menunjukkan kualitas estrus yang lebih baik, onset yang lebih cepat, dan durasi yang lebih lama daripada metode sinkronisasi yang sama tanpa penambahan suplemen $\mathrm{Zn}$. Penambahan suplemen $\mathrm{Zn}$ menunjukkan estrus yang seragam sehingga sinkronisasi estrus tetap terjadi dengan kualitas yang lebih baik.

\section{UCAPAN TERIMA KASIH}

Penulis mengucapkan terimakasih kepada drh. Agung Budiyanto, M.P., Ph.D. dan Dr. drh. Yuriadi, M.P selaku pembimbing dalam penelitian. Salam hormat dan terimaksih tidak lupa penulis haturkan kepada Bp. H. Aprila Respati Adi (Didik) selaku pemilik Peternakan Bhumi Nararya Farm.

\section{DAFTAR PUSTAKA}

Amen, M.H.M., \& Al-Daraji, H.J. (2011). Influence of Dietary Supplementation with Zinc on Sex Hormones Concentrations of Broiler Breeder Chickens. ISSN 1680-5194.

Asian Network for Scientific Information. 2011. Pakistan Journal of Nutrition 10 (11): 1089-1093.

Badan Pusat Statistik. (2015). Populasi Ternak Indonesia 200-2014. www.bps.go.id/webbeta/frontend/linkTabelstatis/ print/id/1506.

Cavalcanti, A.S., F.Z. Brandão, L.A. Garcia, Nogueira, and J.F. Fonseca. 2012. Effects of GnRH administration on ovulation and fertility in ewes subjected to estrous synchronization. Revista Brasileira de Zootecnia 41 (6): 1412-1418.

Evans, A.C.O. (2003). Characteristics of Ovarian Follicle Development in Domestic Animals. Reprod Dom Anim, 38, 240-246. 
Frandson, R.D., Wilke, W.L. \& Fails, A.D. (2009). Anatomy and Physiology of Farm Animals. $7^{\text {th }}$ Edition. Wiley-Blackwell.

Gonzales, A.B. \& Veiga, A.L. (2005). Ovarian Follicular Dynamics and Dominance Effect in Sheep. VI Convegno Nazionale SOFIVET-Stintino (SS).

Holtz W Sohnrey, B., Gerland, M., and Driancourt, M.A. 2007. Ovsynch synchronization and fixed-time insemination in goats. Theriogenology 69 (2008): 785-792.

Karokaro, S. (2004). Kontribusi Usaha Peternakan Kambing dalam Pembangunan Pertanian. Lokakarya Nasional Kambing Potong.

Kundu, M.S., De, A.K., Jeyakumar, S., Sunder, J., Kundu, A., and Sujatha, T. 2014. Effect of Zinc Supplementation on Reproductive Performance of Teressa Goat. Veterinary World. EISSN: 2231-0916. www.veterinaryworld. org/Vol.7/ June-2014/3.pdf.

Noakes, D.E., Parkinson, T.J., \& England, G.C.W. (Eds.). (2008). Arthur's Veterinary Reproduction and Obstetrics. Eight Edition. Saunders an imprint of Elsevier Limited. Philadelphia. USA.

Tian, X. and Diaz, F.J. 2012. Acute Dietary Zinc Deficiency before Conception Compromises Oocyte Epigenetic Programming and Disrupts Embryonic Development. Developmental Biology 376 (2013): 51-61.

Vinoles, C., Meikle, A., \& Martin, G.B. (2009). Short-term nutritional treatments grazing legumes or feeding concentrates increase prolificacy in Corriedale ewes. Animal Reproduction Science 113, 82-92. Journal homepage: www.elsevier. com/ locate/anireprosci.

Yacoub A.N., Gauly, M., Sohnrey, B., \& Holtz, W. (2011). Fixed-time deep uterine insemination in PGF2_-synchronized goats. Theriogenology 76, 1730-1735. 